\title{
9 The Early Modern Bible between Material Book and Immaterial Word
}

\author{
Wim François
}

In his book, Used Books: Marking Readers in Renaissance England from 2008, William Sherman rightly observed that 'the transcendence of their texts notwithstanding, Bibles ... are material objects, created, circulated, and used by actual people, in specific settings, for particular purposes.' Taking this fruitful insight as a starting point, this article will propose a model to study early modern Bibles from three different perspectives: (1) text and paratext, which implies a concentration on the 'transcendent' content; (2) the objective features of certain Bible editions, such as typefaces, layout, and images, among others; (3) traces of appropriation in individual copies. This threefold relationship determines the character of a certain edition or copy and may also inform the researcher about intended groups of readers, as well as its actual use. Given the timeframe in which this article is situated, the Reformation Era, speaking about the characteristics of a Bible also involves dealing with its confessional color, since confession was tremendously important in the period under consideration. ${ }^{2}$ The theoretical framework presented in this article will be illustrated through several examples of specific Bible editions. These copies are for the most part taken from the vernacular Bible tradition of the Low Countries during the sixteenth century, but the framework that we sketch can also incorporate examples from other traditions.

\section{Text and Paratext}

In order to determine the place of a particular Bible edition within the confessionalized landscape of the Early Modern Era, Church historians often use a kind of checklist of biblical passages that are liable to a confessionally-colored rendering and that facilitate the scholar in situating an edition within a determined camp. One of the most famous examples concerns the translation of Romans 3: 28 which reads 'For we account a man to be justified by faith, without the works of the law' (Douai Reims Version). Luther added the famous word 'alone' to 'faith,' to make the translation congruent to his sola fide-doctrine: 'Therefore we assume that a man is justified without the works of the law, by faith alone.' But since the word 'alone' is not to be found in the Greek original, its addition became a bone of contention between Lutherans and Catholics (and even between Lutherans and non-Lutheran Protestants), and thus an identitymarker of the former.

Apart from the translation of specific biblical passages, the paratextual materials may also display an outspoken confessional character that becomes evident through prefaces, prologues to individual Bible books, summaries above the chapters, and/ or marginal glosses. Such paratextual materials were designed to serve the specific 


\section{0}

aim for which the Bible edition was intended, be it for personal reading, following the official liturgy of the Church, or for use in the 'conventicles' of religious dissident groups. These elements deliberately steered the interpretation of the reader in a certain direction, a not so difficult task given their placement at the beginning of a book or chapter, or adjacent to the text in the margin. ${ }^{3}$ In this regard, Protestants borrowed paratextual materials from Erasmus, and of course from Luther and other Reformers, whereas Catholics chose 'orthodox' materials, such as the prologues of Saint Jerome to accompany the Bible books as found in the Vulgate. Eventually, the Catholic Church preferred a 'naked' Vulgate translation, devoid of all paratextual materials, but one made subservient to the official liturgy of the Church through the inclusion, among other elements, of a saints' calendar and a table indicating which Epistles and Gospels were to be read on each Sunday and feast day.

One last confessional marker for an edition was the choice of the biblical canon itself. Whereas Catholics accepted the extended canon as it was found in the medieval copies of their Vulgate, Luther claimed that the Old Testament books that were not included in the Hebrew Bible (but only in the Greek) should not be received as canonical. Luther relegated these 'apocrypha' to an intertestamental section between the Old and the New Testament. He even created a kind of deuterocanonical appendix within the New Testament and included Hebrews, James, Jude and Revelation in this category. He not only called into question the apostolic origin of these works, but even denounced their failure to express the core of the Gospel as the good news of salvation from sin by Christ alone. ${ }^{4}$

\section{Objective Features: Typefaces, Layout and Images}

Theories on the 'Bible as an object' have raised the question of how 'objective' features of Bibles could be used as agents of a definite confessional character and may inform us about intended readers and actual users. In this regard, attention will now be paid to particular features such as layout, typefaces, images, and other pictorial elements that translators, publishers, and printers chose for their Bible editions in order to give them a particular (confessional) character and for a certain audience. In a sixteenth-century context, the 'stakeholders' mentioned may also have taken censorship measures into account, so that a book censor could have, either directly or indirectly, been involved in its production.

Luther was particularly skillful in exploring the possibilities of a book's layout in order to instill his views into the reader's mind. As regards the canon, the table of contents from his September Testament of 1522 emphasized in a visual way that Hebrews, James, Jude, and Revelation constituted a kind of deuterocanonical appendix to the New Testament by separating them from the 'fully canonical' books of the New Testament with a large blank space and the omission of a (serial) number. ${ }^{5}$

Luther, moreover, altered the common division of the New Testament text into pericopes and, concomitantly, adapted the layout and division into paragraphs on the printed page. According to this method, he took care to put biblical verses that he wanted to highlight theologically at the beginning of a new paragraph and had them start with an indentation. Such a layout, together with the blank line it created before the text, made the passage stand out from the rest of the page, thus giving it emphasis. ${ }^{6}$ In Luther's September Testament of 1522 we see how this happens with 
the aforementioned verse of Romans 3: 28 'Therefore we assume that a man is justified without the works of the law, by faith alone.' In other words, text, paratext - see the marginal glosses - and layout serve Luther's aim, namely to instill into the minds of his readers his theology of justification by faith alone. This technique of indented paragraphs, borrowed from Luther's Bibles, was later taken over in several Dutch and other language - Bibles. ${ }^{7}$

Another interesting example is taken from the New Testament translated into Spanish by the Reformation-minded humanist Francisco de Enzinas and printed in Antwerp by Steven Mierdmans in 1543. In Romans 3, we notice that two verses that are important for the Lutheran doctrine of justification by faith alone are highlighted through the printing of key words in capital letters (Figure 9.1):

Romans 3: 22 Verdaderamente la justiçia de Dios es por la fee de Jesu Christo, para todos y sobre todos los que crein. ['And indeed the righteousness of God is by faith of Jesus Christ unto all and upon all them that believe.']

Romans 3: 28 Concluimos pues que el hombre es iustificado por la fee, sin las obras de la ley. ['Therefore we conclude that a man is justified by faith, without the deeds of the law.']

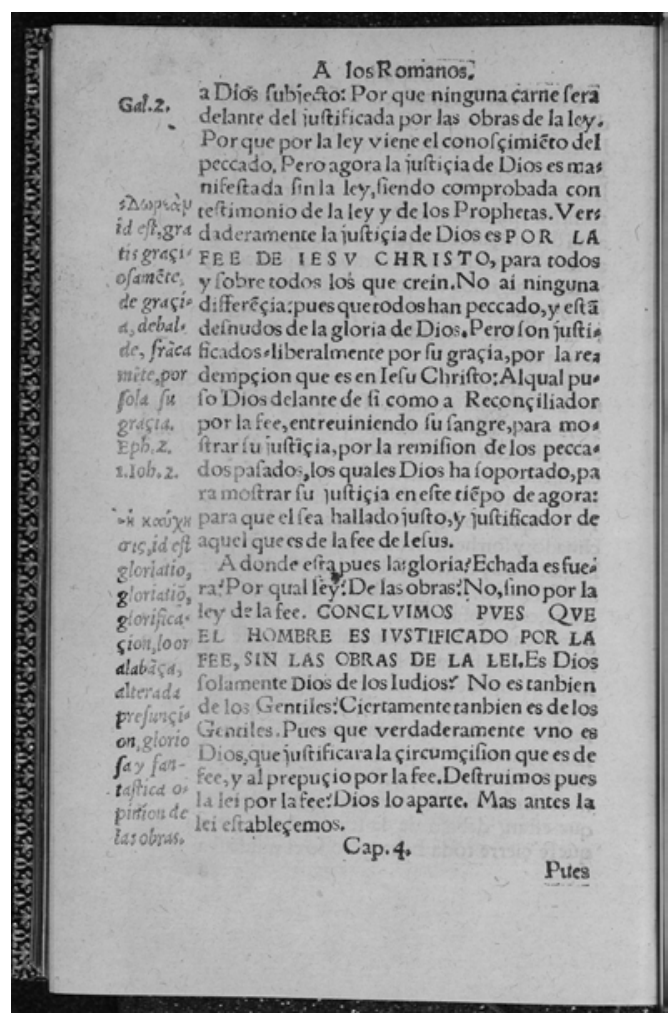

Figure 9.1 El nuevo testamento de nuestro Redemptor y Salvador Iesu Christo ...., trans. Francisco de Enzinas ([Antwerp: Steven Mierdmans], 1543), to Rom. 3. Brussels, Koninklijke Bibliotheek van België, LP 28636. 


\section{The Early Modern Bible}

Through the addition of a marginal gloss to Romans 3: 24 explaining the Greek term dorrean 'gratis, for free,' Enzinas emphasized in concurrence with the Lutheran tradition that God had offered his grace to man through the salvific death of Jesus at the cross and that man was justified by faith alone in God's graceful gift and not by the alleged merits of his works. In contrast to Luther, Enzinas did not add the word 'alone' to the translation of Romans 3: 28, but preferred - obviously for reasons of cautiousness - to highlight the same theology through more subtle means, namely the use of capital letters and the addition of marginal annotations. ${ }^{8}$

In other Bible editions, hands with pointing index fingers (maniculi) - which were already used in medieval manuscripts - were printed in the margin. ${ }^{9}$ This is, for example, the case in the Bible (both in the Old and the New Testament) printed by Willem Vorsterman in Antwerp in 1528. These manicules were now used to point to passages with a certain (theological) interest, often to texts that were important to the Reformational ideas of sola scriptura, sola gratia, and sola fide. We refer only to two examples: Romans 4: 6-7 'just as David also described the blessedness of the man, to whom God imputes righteousness apart from works: "Blessed are those whose lawless deeds are forgiven, And whose sins are covered"' (New King James); Ephesians 2: 8-9 'For by grace you are saved through faith, and that not of yourselves, for it is the gift of God; Not of works, that no man may glory.' ${ }^{10}$

It is important to notice that Vorsterman's 1528 Bible was devised as an 'orthodox' alternative to the famous Liesvelt Bible, the first edition of which was published two years earlier, but which was viewed with suspicion because of its Reformation-minded characteristics. However, several Reformation-minded passages were again included in Vorsterman's first edition, likely because one or more compositors in Vorsterman's office was sympathetic to religiously dissident ideas and deliberately ignored the corrections that were presented to them, to the great embarrassment of the 'correctors' and the printer-publisher. Therefore Willem Vorsterman brought, within a few months, in 1529, a revised version of the New Testament onto the market, with the contested biblical passages now adapted to the Vulgate, and with most of the manicules removed (Figures 9.2(a) and 9.2(b)).

Before focusing on Bible illustrations in the strict sense of the word found in Dutch Bibles, our attention is captured by an interesting pictorial element that we find in the Dutch 'Luther' Bibles published by Jacob van Liesvelt in 1535 - already mentioned above - Hansken (I) van Liesvelt in 1538 and Jacob van Liesvelt in 1542. The 'prettily arranged lines of the last paragraph of the Old Testament' are followed by a rose. This rose is also to be found on the title page of the New Testament part of the 1538 and 1542 Bibles. This was likely a subtle reference to Luther's rose, which the Reformer had adopted as his seal by 1516-17 and which he had used since 1519 as an authentication of the printed materials that went through his hands (in distinction to the many pirated editions which frequently contained mistakes). In regard to his Bible editions, the copyright mark appeared for the first time in Luther's edition of Joshua-Esther from Wittenberg in 1524 and was even printed on the title page of his edition of the Psalms from the same year. From the 1530s onward, the Luther rose turned into a mere ornamental marker. ${ }^{11}$ Van Liesvelt, who is known for his ability to take prompt advantage of all kinds of new evolutions in the world of books and religion, was eager to include the rose in his editions. ${ }^{12}$

We now turn our attention to the use of illustrations in vernacular Bibles. In this regard it should be emphasized that the large majority of the illustrations in Dutch 

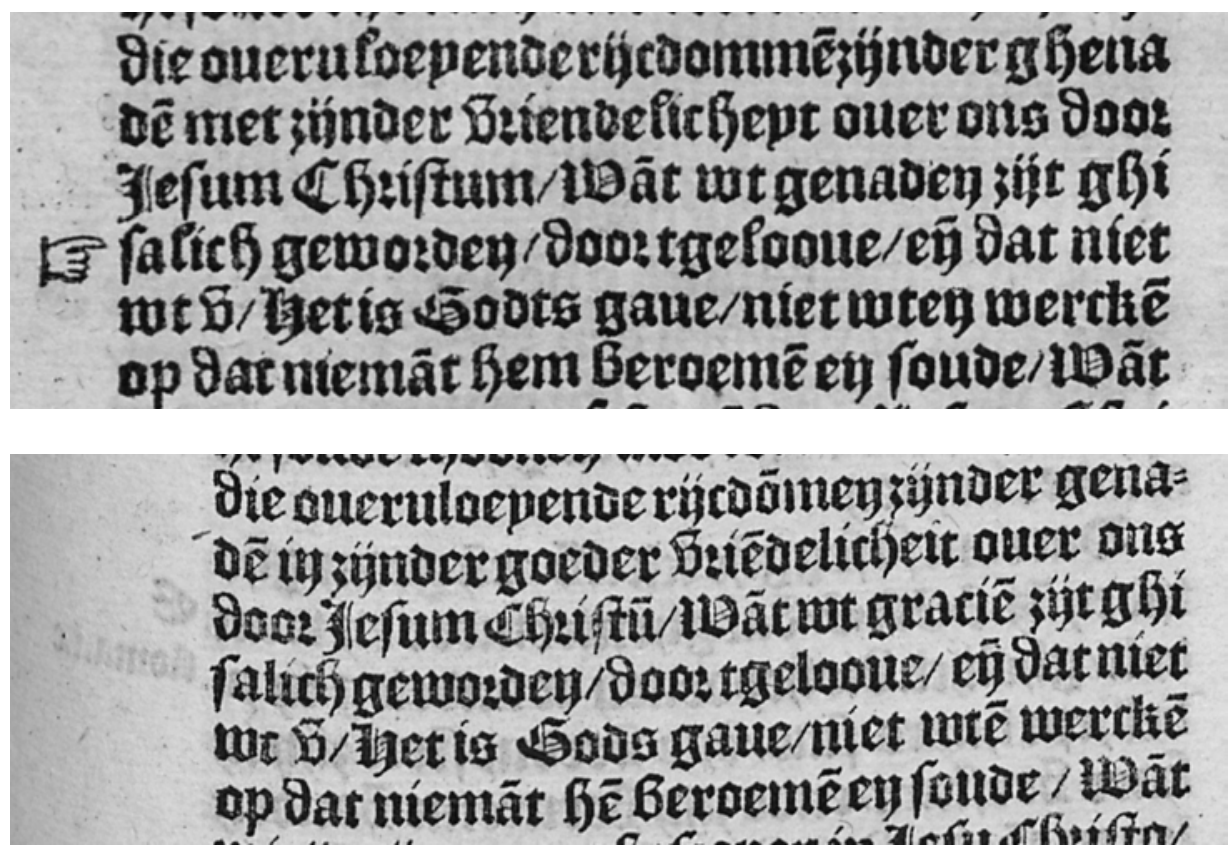

Figure 9.2(a) and 9.2(b) De Bibel Tgeheele Oude ende Nieuwe Testament... (Antwerp: Willem Vorsterman, 1528) and Tgeheele Nieu Testament ... (Antwerp: Willem Vorsterman, 1529), to Eph. 2: 8-9. Leuven, KU, Maurits Sabbe Library, GBIB P22.055.1/F\% $\mathrm{BIJB} / 1528-29$.

Bibles aim at providing the reader with a visualization of the literal meaning of the text and, as such, offer an aid to comprehend the heart of the biblical story, although the selection of elements from the narrative that are visualized is in any event a 'hermeneutical fact. ${ }^{13}$ In the context of this contribution, it is important to note that the large majority of the Bible illustrations have no confessional color and were used indiscriminately in Protestant or Catholic Bibles. With regard to the (Old Testament) illustrations included in sixteenth-century Dutch Bibles, it should, however be observed that an important part of them bear pictorial features that go back ultimately to the late Middle Ages, making them open to a typological interpretation. Three of the often copied German illustration cycles in Dutch Bibles - Erhard Schön's series for Jacob Sacon's Lyons Vulgate editions (1518-21), Hans Holbein's Icones (c.1525; first published in book form in 1538), and Hans Sebald Beham's Biblische Historien (1533) drew extensive inspiration from the so-called Cologne Bible printed by Heinrich Quentel in 1478-9, whereas the Italian Malerbi Bible published by LucAntonio di Giunta in Venice 1490 is also an important source. The illustrations accompanying the description of the Ark of the Covenant, the Tabernacle of the Desert, and Solomon's Temple go back ultimately to the pictorial tradition of the Postilla by Nicholas of Lyra (c.1270-1349). It remains an open question, however, whether, without receiving any guidance, the users of sixteenth-century Bibles were able to see all the Old Testament scenes depicted as a pre-figuration of the salutary events of the life of Christ, his mother, 


\section{The Early Modern Bible}

or the mysteries of the Church. It is also true that a part of the sixteenth-century readership, in particular those readers who were influenced by the 'new' humanist and Reformation-minded ideas, also harbored critical thoughts regarding the late medieval typological tradition. ${ }^{14}$

Whatever the case may be, in the largely Catholic Vorsterman Bible of 1533-4 and in the editions published in its wake, glosses and annotations were included in the margin to make the typological relationships of many images explicit (in addition to providing other kinds of information). ${ }^{15}$ The Catholic accents are striking, as one can see from the annotation to the picture illustrating Exodus 3, Moses before the burning bush that is not consumed. In the margin we read the annotation: 'This bush burned but was not consumed, which is a figure of the immaculate virginity of the Mother of God, Mary. ${ }^{16}$ The bush that burned without being consumed was traditionally seen as a pre-figuration of Mary and signified her conception of Jesus 'without being consumed by the flames of concupiscence' and thus without compromising her virginity. This is at least the explanation we also find in the late medieval block books, as the Biblia Pauperum and Speculum humanae salvationis. ${ }^{17}$ The word 'immaculate,' onbevleckt in Middle Dutch, may also recall Mary's Immaculate Conception, the belief that Mary was kept free from the stain of original sin from the very moment of her conception (which should not be confused with her lasting virginity). The view, however, that the burning bush was a pre-figuration of Mary's Immaculate Conception was not as widespread as the belief that it was a pre-figuration of Mary's virginity, and the view developed only gradually, when the doctrine of the Immaculate Conception became more and more accepted, with the Franciscans showing themselves to be its most zealous propagators.

At Exodus 25 we find an image of the table on which the so-called 'loaves of proposition' or 'showbread' were to be placed, an image taken from the Postilla tradition. This was of course considered as a pre-figuration of the Sacrament of the Altar. ${ }^{18}$ We do not, however, find this motif in Speculum humanae salvationis or in Biblia Pauperum. In the Middle Ages the loaves of proposition were considered to be a figure of God's nourishing Word, but in early modern Catholic exegesis, precisely in dispute with the Protestants, they were increasingly interpreted as a pre-figuration of the Sacrament of the Altar. ${ }^{19}$

There are, however, a few exceptions to the general non-confessional character of biblical illustration programs. In this regard we cannot avoid referring to the 21 illustrations of the Apocalypse which Lucas Cranach made for Luther's September Testament of 1522 and which served as an inspiration for Hans Holbein's illustration cycle for the edition of Luther's New Testament that appeared in 1523 with Thomas Wolff in Basel. It is generally known how the Beast coming out of the Abyss according to Apocalypse 11: 7 (identified by Luther with the Antichrist), the Beast spitting the unclean spirits from Apocalypse 16: 10-13, and the Whore of Babylon from Apocalypse 17: 1-6 the 11 th, 16th, and 17 th images respectively - were depicted wearing a papal tiara. Holbein had preserved the papal tiara, although in Luther's December Testament of 1522, the Duke George of Saxony, commanded that the tiara be replaced with a simple crown in order to attenuate the harsh anti-Roman character. ${ }^{20}$

Equally interesting are the 14th and 18th images, dealing with 'Angels proclaiming the day of judgment and the fall of Babylon,' and 'The burning of Babylon and a mighty angel casting a great (mill)stone into the sea,' respectively. Holbein's depiction of corrupt Babylon clearly resembles Rome and its Castle of the Holy Angel, which 
was the fortified palace of the popes in that period. It is usually accepted that the picture is a copy of the right half of the representation of Rome from the Nuremberg Chronicle by Hartmann Schedel (1493). It is striking, however, that in Germany these images were not considered as anti-Roman or, at least, their anti-Roman slant was so discrete that they were not regarded as provocative. They were not removed from the December Testament of 1522 . Even the New Testament by Hieronymus Emser that was published in 1527 by Wolfgang Stöckel in Dresden and that offered a vulgatized version of Luther's New Testament, still has the angel on the Castel Sant'Angelo, whereas the tiaras worn by the Beasts and by the Whore of Babylon were removed.

Holbein's series lies at the basis of most Apocalypse illustrations in the Dutch New Testaments and Bibles of the sixteenth century. Only a few printers, however, dared to keep the papal tiaras in the 11th, 16th, and 17th woodcuts. Among them are two early Reformation-minded Dutch New Testaments, namely Hiero Fuchs's 1525 Cologne edition and Hans (I) van Ruremund's edition published in Antwerp in the same year and in which the same woodcuts were used. ${ }^{21}$ Apart from the New Testament editions of Fuchs and Van Ruremund, the complete Bible edition of Henrick Peetersen van Middelburch from 1535 and his New Testament of 1538 also contain an image of the Whore of Babylon wearing a papal tiara on her head (17th image), whereas the tiara had been replaced by a simple crown in the 11th and 16th images. In all other editions of Dutch Bibles or New Testaments of the said period, the papal tiaras have disappeared with the traces of the cutting away of the upper elements of the tiara often visible on the woodcuts.

Inversely, most Dutch Bible editions from the period have preserved the angel on top of the Castel Sant'Angelo-shape fortress of Babylon (14th and 18th pictures), as was the case in Germany. However, Willem Vorsterman decided to remove it. In his thoroughly Catholic Dutch New Testament of August 1530, Vorsterman had already removed the angel from the 14th print, whereas the 18th still retained it (the woodblocks used are borrowed from Jan van Ghelen in 1528). In the New Testament of November 1530, the angel was removed even from both pictures of the castle (the woodblocks are those Vorsterman had already used for his French New Testament of 1529). In the complete Bible editions of 1532 and later, the same Apocalypse woodblocks were once again used, thus displaying Babylon without an angel on the top of its castle. It is beyond doubt that Vorsterman, who aimed at bringing good Catholic Bibles onto the market, wanted to avoid every identification of the Castle depicted in his Bible with the Castel Sant'Angelo in Rome. For this was what the Reformers had aspired to, namely identifying apocalyptic Babylon from John's Revelation with contemporary Rome, the see of the pope whom they considered to be the Antichrist. ${ }^{22}$

Apart from the tiara-wearing pope, Reformation-minded Bibles show us pictures of monks and clergy in very unflattering circumstances, which may be viewed as an anticlerical sneer (a phenomenon that was not at all unfamiliar to the inhabitants of the Low Countries, since the late Middle Ages onwards).$^{23}$ In the literature on illustrations in Dutch Bibles, other alleged examples of confessionally inspired images have been put forward, although such a confessional reading can rarely be maintained after serious scholarly consideration. ${ }^{24}$ What remains is the overall impression that Bible illustrations are, to an important degree, confessionally neutral and designed to 'create a summarization of the biblical narratives in immediate and clearly observable images of the story.' 25 The watershed distinction between Catholic and Protestant Bibles in the Low Countries occurred in the 1550s, when the use of images disappeared almost 


\section{6}

completely from Protestant Bibles, which only preserved the didactic or explanatory prints showing the Temple and the Tabernacle, as well as some maps of the Holy Land. Catholic Bibles, in contrast, continued to be copiously illustrated. ${ }^{26}$

\section{Traces of Appropriation in Individual Copies}

In a last part of this article, we will leave the focus on how translators, publishers, and printers - whether or not in debate with the censors - conceived the production of a Bible translation in order to study how owners and users appropriated the work. The appropriation of a Bible book may be described according to a tripartite division, namely users' traces, owners' marks, and content-related interventions such as marginal notes and censorship measures. ${ }^{27}$ The question of whether a book was actually read requires one to pay attention to objective users' traces: pages well-thumbed at the edges, irregular edges to the text-block or, only occasionally, traces of fire which may have been caused by reading by candlelight. There are even examples of books containing food stains.

Apart from the 'objective' traces that users left behind, they often deliberately introduced all kinds of annotations. The first and most common inscriptions are data of provenance and ownership notes. The owners of Bibles may have been convents and monasteries, individual friars and sisters, clerics living in the world, or laymen and women. In some Bible copies, we even find genealogies in the sense that important family events, such as births, marriages, and deaths, are recorded. These are often found on a blank leaf at the beginning or end of the book, or in between the Old and New Testaments. In addition, references to what the owners saw as important historical events have been written down, thus marking their own place in history (Figure 9.3). ${ }^{28}$ Many Bibles that were originally in lay hands eventually came into the possession of monasteries when they were donated or bequeathed.

Furthermore, we find copies containing extensive underlining, often crudely executed, selective marginalia, as well as larger annotations that may inform us about the theological ideas of the owner and their confessional color - provided that we are able to get through the paleographical nightmare (Figure 9.4). ${ }^{29}$ In a heavily annotated copy of the 1533-4 edition of Vorsterman's Bible, we see how the reader has written an additional note to the marginal gloss giving a typological explanation of 'Moses before the burning bush.' This note reads: 'Inviolate, intact, and chaste art Thou, O Mary'30 (Figure 9.5). Here, indeed, 'printed marginalia [are] imitated or elaborated in handwritten annotations. ${ }^{31}$

In some cases, even extra pages were added to make the copy usable for a specific aim the owner had in mind. The Maurits Sabbe Library of the University of Leuven preserves a remarkable copy of the Catholic New Testament printed in Leuven in 1548. As is usually the case with books of this type, the text of the New Testament was followed by the text of the Epistle readings taken from the Old Testament that were read during mass (in this instance with an emphasis on the lessons of Lenten Fast). However, a beautiful handwritten quire has been added containing the Dutch text of several Old Testament lessons that were not included in the printed part. The quire has been immediately (and not at a later stage) bound together with the printed work, with a book binding which is still the original one and is stamped with an image of the Habsburg Emperor Charles V. ${ }^{32}$ In this way the booklet was tailored even more to the need of the owner or user to help him or her to follow the scriptural readings at mass. 


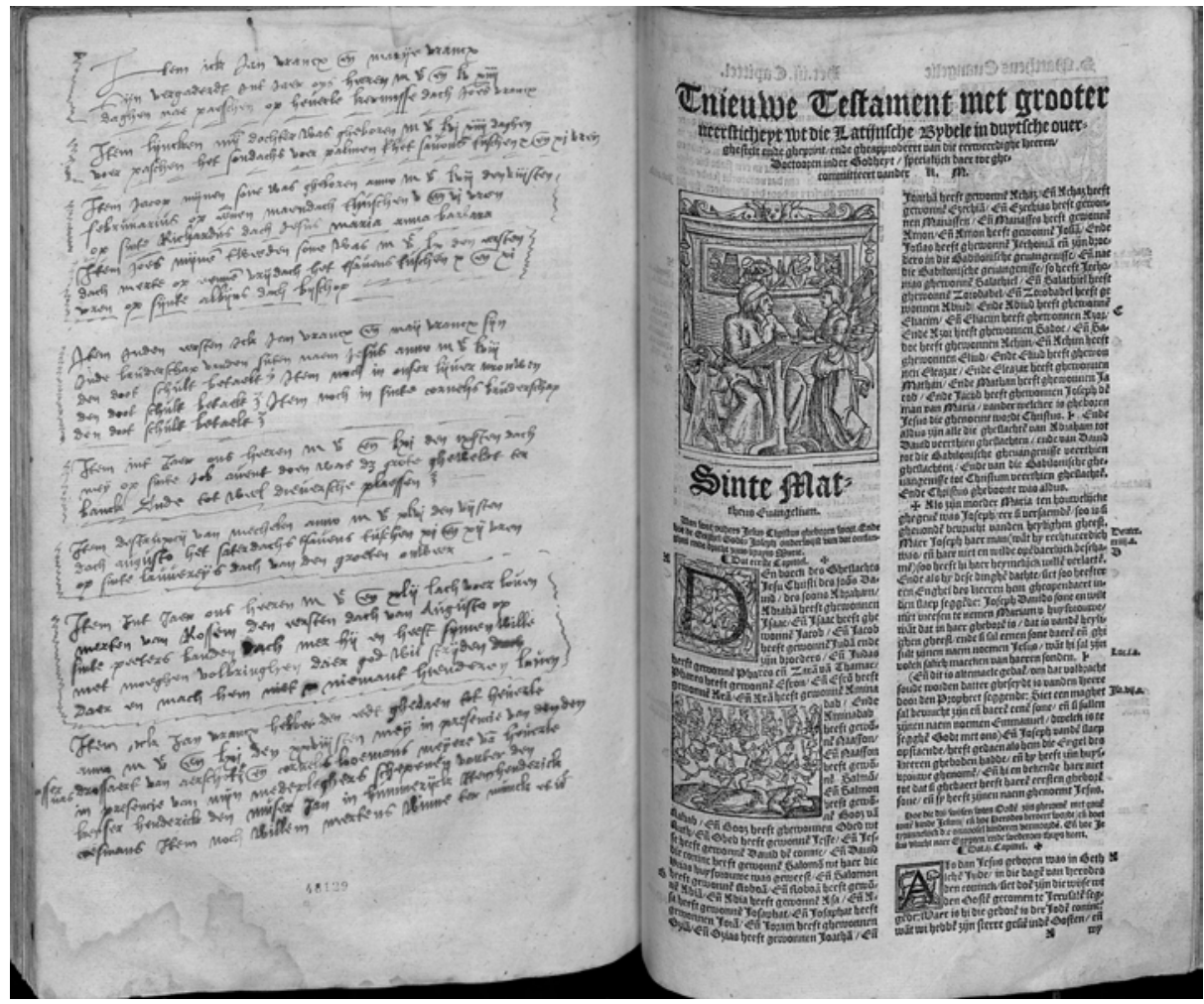

Figure 9.3 De Bibel inhoudende het oude ende nyeuwe Testament ..., trans. Nicholas van Winghe (Antwerp: Widow Henrick Peetersen van Middelburch for Marie Ancxt, 1560). Leuven, KU, Maurits Sabbe Library, GBIB P22.055.1/Fo/ $\mathrm{BIJB} / 1560$.

Later, in 1640, the book was in the possession of a religious sister named Elisabeth de Gru(u)tere. ${ }^{33}$

In rare cases, we even find interesting examples of how texts and images in Bibles were subject to active censorship. In a copy of Liesvelt's 1535 Bible, preserved in the Maurits Sabbe Library, we see how the Lutheran addition 'alone' has been carefully scratched out from Romans 3: 28.

The Maurits Sabbe Library also preserves a Dutch Catholic Bible, translated by the Carmelite Alexander Blanckart and printed by Jaspar van Gennep in Cologne in 1547-8. The title page border shows us a variation to a renowned picture by Anton Woensam, called 'of Worms' $(\dagger 1541)$ and is vividly colored by an unidentified user (Figure 9.6). On top of the page border we find a variation to the famous staircase of grace. Jesus is showing the wounds in his hands and his side to the Father, who sits enthroned as a severe judge (see the accompanying passages from Zacharias 1: 15 'And I am angry with a great anger with the nations,' and Deuteronomy 32: 23 'I will spend my arrows among them' [DRV]). Jesus' act should be seen as an act of intercession on behalf of a condemned mankind. Just as God created Eve from Adam's rib depicted below on the page border - Jesus has opened the possibility for mankind 


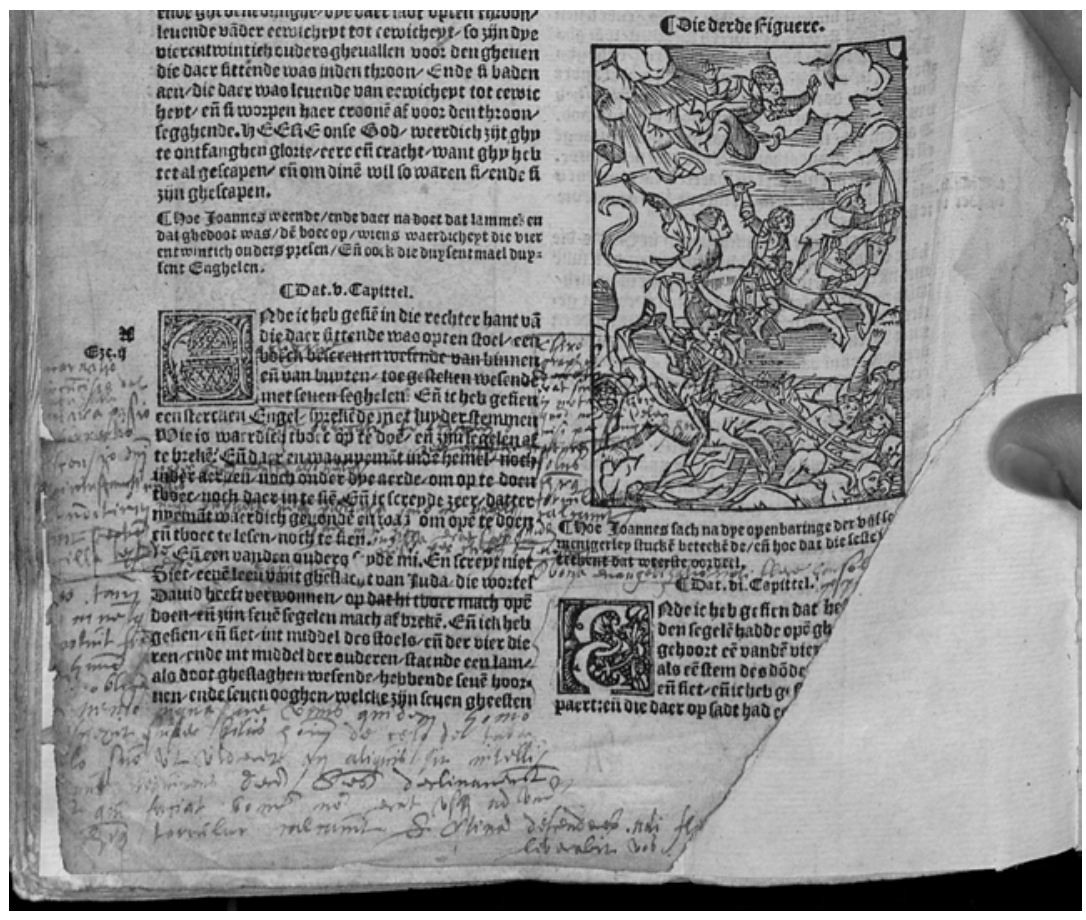

Figure 9.4 Den Bibel Tgeheele Oude ende Nieuwe Testament... (Antwerp: Willem Vorsterman, 1533-4), to Apo 5. Leuven, KU, Maurits Sabbe Library, GBIB $\mathrm{P} 22.055 .1 / \mathrm{F}^{\circ} / \mathrm{BIJB} / 1533-34$.

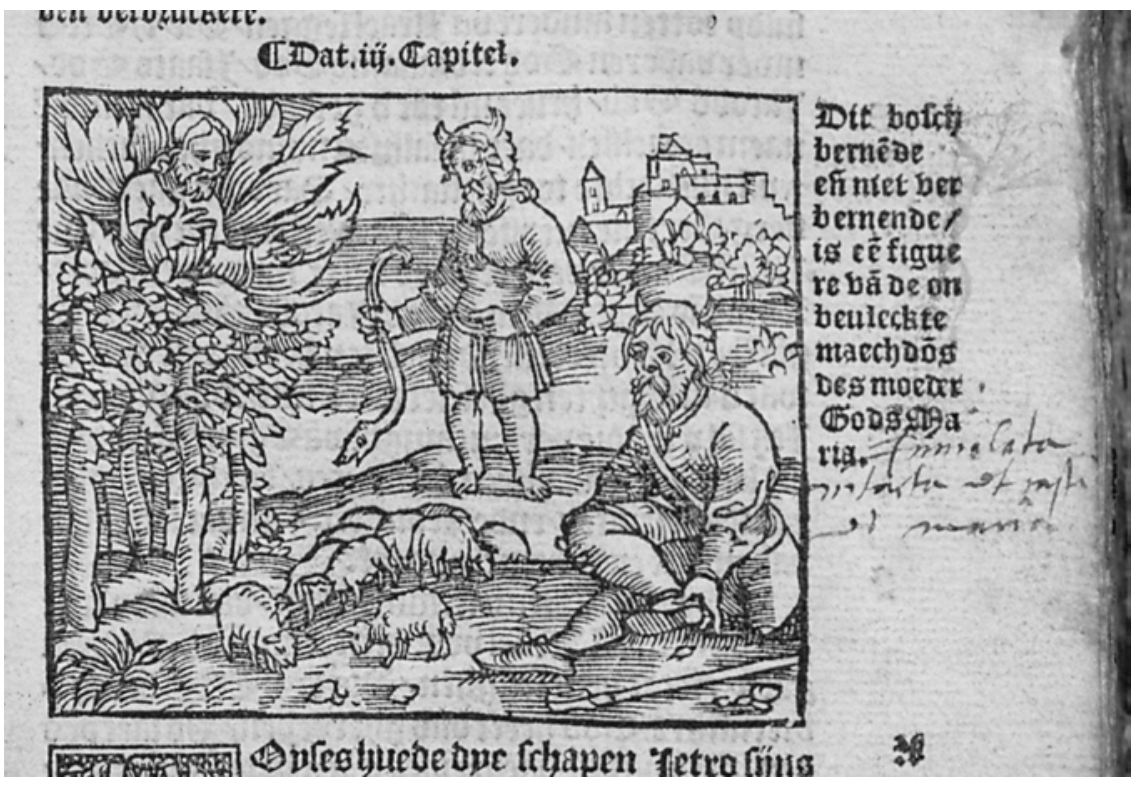

Figure 9.5 Den Bibel Tgeheele Oude ende Nieuwe Testament... (Antwerp: Willem Vorsterman, 1533-4), to Ex. 3. Leuven, KU, Maurits Sabbe Library, GBIB $\mathrm{P} 22.055 .1 / \mathrm{F} / \mathrm{BIJB} / 1533-34$. 


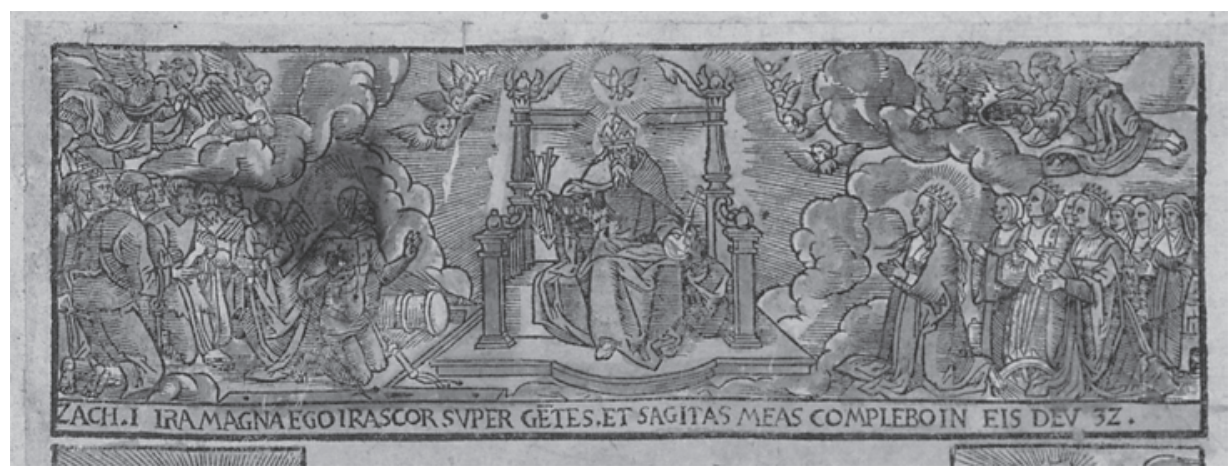

Figure 9.6 Die Bibel, wederom met grooter nersticheit oversien ende gecorrigeert ..., trans. Alexander Blanckart and Joannes Sprengel (Cologne: Jasper van Gennep, 1547-8), front page. Leuven, KU, Maurits Sabbe Library, GBIB $\mathrm{P} 22.055 .1 / \mathrm{F} / \mathrm{BIJB} / 1548$.

to be restored and saved through the open wounds in his hands and his side. On the other side of Jesus, Mary is also implied in this act of intercession before God's throne. Apart from the fact that the title page has been colored, the presence of an inkblot just along the length of Jesus' figure is striking. This inkblot has no accidental cause, but has most probably been applied as a deliberate censure of the image. The reason is that Jesus is not at the place where He should be, namely enthroned at the right hand of God, but is depicted on a lower step, kneeling before the Father, and even on the same level as Mary. The hypothesis of a deliberate censorship is confirmed by the fate of other images of the same kind, the most famous example being the painting of the staircase of grace by Abraham Bloemaert (1564/6-51), which is currently still in the Saint-John's Cathedral in 's-Hertogenbosch (the Dutch part of Brabant). Immediately after its arrival there $c .1615$, the painting evoked the discontentment of Antonius Bruynincx, a member of the cathedral chapter. On order of the bishop of Den Bosch, Bloemaert made a pen drawing of the painting, which was sent to the Louvain theologians for further examination. The theologians did not hesitate to issue a negative assessment, for the reasons explained above. ${ }^{34}$

A last example of how users or readers may deal with books and images is to be found in a Catholic New Testament edited by the Jesuit Frans de Coster or Costerus and published in 1614 by Joachim Trognaesivs in Antwerp. The Bible was explicitly destined for the market in the Dutch Republic. In order to be acceptable to a Protestant readership, the edition did not contain images. Since the aim was to bring the Protestants of the North back to Catholicism, anti-Protestant glosses in the New Testament were included in order to convince them of the necessity of such a step. However, the Maurits Sabbe Library preserves a copy of Costerus's edition, in which lots of images are carefully inserted or glued on the relevant pages of the New Testament. The work dates from the middle of the seventeenth century and contains images from engravers such as Cornelis Galle (1576-1650), Cornelis Schut (1597-1655), Martin van den Enden (1605-73), Joannes Meyssens (1612-70), and Caspar Huberti (1619-84), among others. The aim was, of course, to adapt this New Testament for Catholic devotional practices, providing a meditative apparatus in both text and image that would nourish the soul (Figure 9.7). 


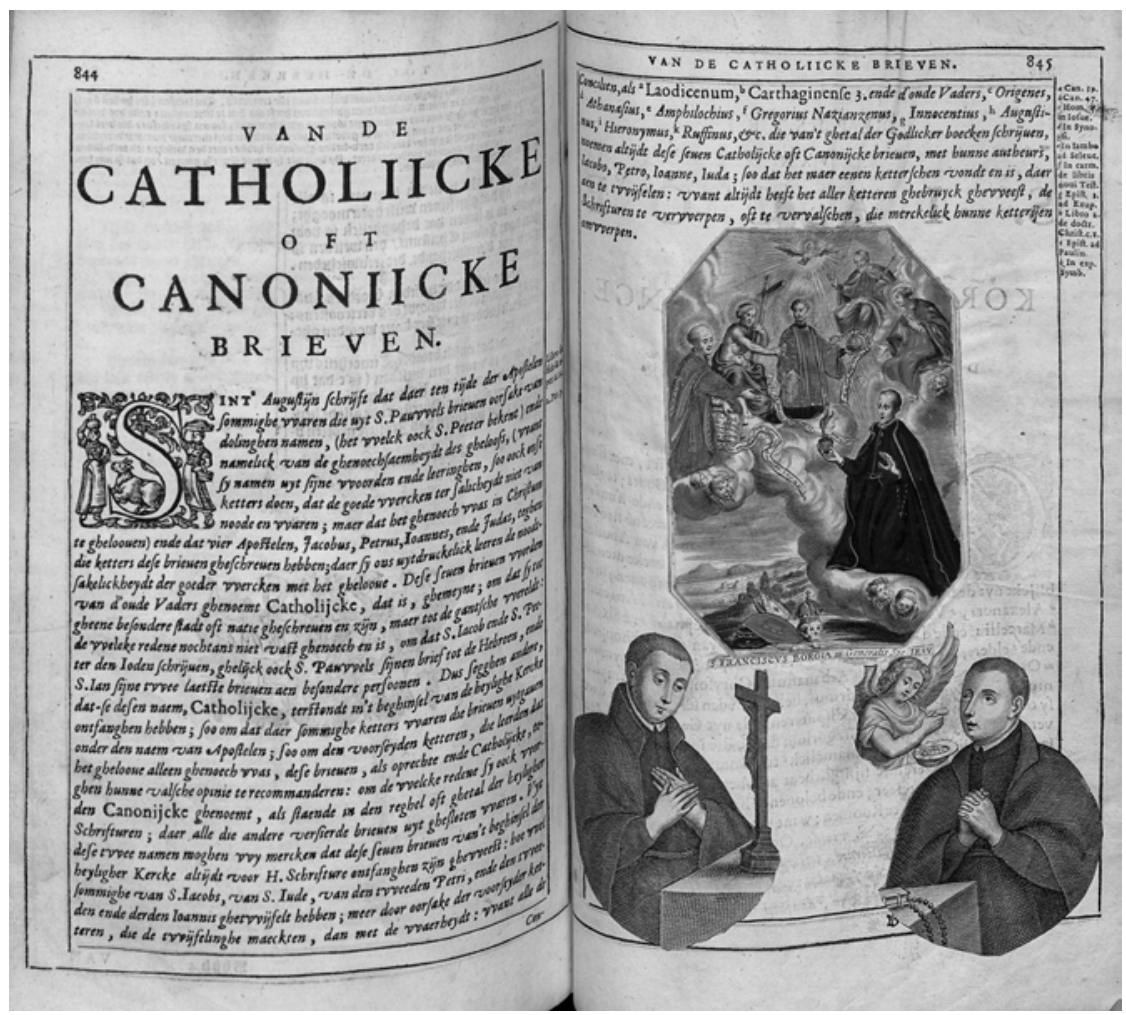

Figure 9.7 Het nieu testament onses Heeren Iesu Christi met korte uytlegghinghen ..., ed. Franciscus Costerus (Antwerp: Ioachim Trognaesius, 1614. Leuven, KU,

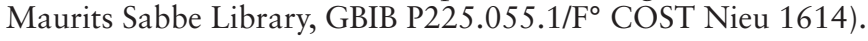

\section{Conclusion}

The study of the Bible in the Reformation should not only concentrate upon text and paratext, but should also take into account the material aspects of certain editions and even devote an increasing interest in individual copies. Indeed, the study of individual copies may inform us about who actually read a certain Bible. A complete view in this regard will require the examination of provenance and other data in a broader set of copies.

This research, however, is liable to a few methodological difficulties. For example, cheap religious books that contained the New Testament or the Epistle and Gospel readings from mass - which were often edited in an octavo, duodecimo or seidecimo format and which were intensively used and read - were often kept in use until they were completely worn out. After such intensive use, these types of books were often thrown away, with the result that they have been lost to research. ${ }^{35}$ The implication here is clear: the books that are the most fascinating for scholars interested in the social history of reading have fewer chances of survival than preciously edited books that were hardly touched. Furthermore, the books that were preserved in monasteries, and 
which were kept in public libraries following the secularization of those institutes, had more chance of survival than books owned by lay people that were constantly passed down to new generations and may have been liable to a lack of interest in some of the new owners. These methodological provisos notwithstanding, many interesting insights regarding actual readership may be expected from the examination of a larger set of individual Bible copies from the Reformation Era. ${ }^{36}$

\section{Notes}

I wish to thank Ms Jennifer Besselsen-Dunachie for her invaluable assistance in translating the text.

1 William H. Sherman, Used Books: Marking Readers in Renaissance England (Philadelphia, PA: University of Pennsylvania Press, 2008), 72.

2 Our theoretical framework is tributary to several authors, among whom Robert Darnton, 'What is the History of Books?,' Daedalus, 111 (1982), 65-83; idem, 'What is the History of Books? Revisited,' Modern Intellectual History, 4 (2007), 495-508; Donald McKenzie, Bibliography and the Sociology of Texts (London: British Library, 1986); Roger Chartier, The Order of Books: Readers, Authors, and Libraries in Europe between the Fourteenth and the Eighteenth Centuries, trans. Lydia G. Cochrane (Oxford: Polity Press, 2007); Roger Chartier, 'The Order of Books Revisited,' Modern Intellectual History, 4 (2007), 509-19.

3 Apart from confessionally colored marginal glosses, other types of printed marginalia in Bible books may claim to be more 'neutral,' such as cross-references to other biblical passages, textual variants, explanations of Hebrew and Greek source words, as well as biblical names, chronological annotations, and so on. But the mere presence of 'linguistic glosses on source words or textual variants' may not be as neutral as it looks at face value, as William Sherman has rightly observed, since "these too created a contested space on the edge of the text and revealed to the readers a multiplicity or indeterminacy in the transmission of God's Word' (Sherman, Used Books, 74). Interesting ideas on printed marginal glosses may also be found in Heidi Brayman Hackel, Reading Material in Early Modern England: Print, Gender and Literacy (Cambridge: Cambridge University Press, 2005), esp. 88-100 and 125-36.

4 Among the numerous works on Luther's Bible translations, the following are useful in the context of this article: John L. Flood, 'Martin Luther's Bible Translation in its German and European Context,' in The Bible in the Renaissance: Essays on Biblical Commentary and Translation in the Fifteenth and Sixteenth Centuries, ed. Richard Griffiths (Aldershot: Ashgate, 2001), 45-70; Mark U. Edwards Jr., Printing, Propaganda and Martin Luther (Berkeley, CA: University of California Press, 1994).

5 Edwards, Printing, Propaganda and Martin Luther, 109-31, here 113. Cf. Flood, 'Martin Luther's Bible Translation,' 54.

6 Cf. Edwards, Printing, Propaganda and Martin Luther, 122-3.

7 Frans A. Janssen, 'The Rise of the Typographical Paragraph,' in Cognition and the Book: Typologies of Formal Organisation of Knowledge in the Printed Book of the Early Modern Period, eds Karl A. E. Enekel and Wolfgang Neuber (Leiden: Brill, 2005), 9-32, at 21-4.

8 Cf. Els Agten, 'Francisco de Enzinas, a Reformation-minded Humanist with a Vernacular Dream: A Spanish New Testament,' Reformation and Renaissance Review, 14 (2012), 219-42, at 235-7. See there for further literature.

9 On the maniculi or manicules: Sherman, Used Books, 25-52, esp. 40-5.

10 Cf. Wim François, 'De Vorstermanbijbel van 1528 en later: naar een katholieke bijbel,' in De Bijbel in de Lage Landen: Elf eeuwen van vertalen, eds Paul Gillaerts et al. (Heerenveen: Jongbloed, 2015), 237-65, here 250. On the Vorsterman Bible, see also Wim François, 'The Compositors' Neglect or the True Story Behind the Prohibition of Vorsterman's Dutch Bibles,' Ephemerides Theologicae Lovanienses, 91 (2015), 239-56.

11 Dietrich Korsch, 'Luther's Seal as an Elementary Interpretation of His Theology,' in Harvesting Martin Luther's Reflections on Theology, Ethics, and the Church, ed. Timothy J. Wengert (Grand Rapids, MI and Cambridge: Eerdmans, 2004), 56-77, at 60; Haimo 
Reinitzer, Biblia deutsch. Luthers Bibelübersetzung und ibre Tradition (Wolfenbüttel: Herzog August Bibliothek, 1983), 144-7; Hans Volz, 'Das Lutherwappen als 'Schutzmarke,"' Libri, 4 (1954), 216-25.

12 Goran Proot, 'Designing the Word of God: Layout and Typography of Flemish 16thCentury Folio Bibles Published in the Vernacular,' De Gulden Passer, 90 (2012), 143-79, at 173.

13 Max Engammare, 'Les représentations de l'Écriture dans les Bibles illustrées du XVIe siècle. Pour une herméneutique de l'image imprimée dans le texte biblique,' Revue française d'histoire du livre, 64 (1995), 117-89.

14 On the decline of the interest in typological associations in the Biblia Pauperum tradition, see Jan Piet Filedt Kok, 'Een Biblia pauperum met houtsneden van Jacob Cornelisz. en Lucas van Leyden gereconstrueerd,' Bulletin van het Rijksmuseum, 36 (1988), 83-110.

15 See also for this section Wim François, 'Typology - Back with a Vengeance! Text, Images, and Marginal Glosses in Vorsterman's 1534 Dutch Bible,' in Imago Exegetica: Visual Images as Exegetical Instruments, 1400-1700, eds Walter S. Melion, James Clifton, and Michel Weemaes (Leiden: Brill, 2014), 89-136, esp. 108ff. Cf. Walter S. Melion, 'Bible Illustration in the Sixteenth-Century Low Countries,' in Scripture for the Eyes: Bible Illustration in Netherlandish Prints of the Sixteenth Century, exhib. cat., Museum of Biblical Art, New York City; Michael C. Carlos Museum, Emory University, Atlanta, eds James Clifton and Walter S. Melion (London and New York: Museum of Biblical Art and D. Giles Ltd, 2009), 14-106, esp. 15-26; Engammare, 'Les représentations de l'Écriture dans les Bibles illustrées du XVIe siècle,' 176-84.

16 Dit bosch bernende ende niet verbernende / is een figuere van de onbevleckte maechdoms des moeder Gods Maria.

17 See also François, 'Typology - Back with a Vengeance!', 120, with references to Biblia Pauperum, ed. Avril Henry (Ashgate: Aldershot, 1987), 51 and The Bible of the Poor [Biblia Pauperum]: A Facsimile and Edition of the British Library Blockbook C.9 d.2, eds Albert C. Labriola and John W. Smeltz (Pittsburgh, PA: Duquesne University Press, 2012), 16, 58, 100, 145-6. Also The Mirror of Salvation [Speculum Humanae Salvationis]: An Edition of British Library Blockbook G. 11784, eds. Albert C. Labriola and John W. Smeltz (Cambridge: Clarke, 2002), 30, 103-4; A Medieval Mirror: Speculum Humanae Salvationis 1324-1500, eds Adrian Wilson and Joyce Lancaster Wilson (Berkeley, CA: University of California Press, 1984), 154; Enriqueta Harris, 'Mary in the Burning Bush: Nicolas Froment's Triptych at Aix-en-Provence,' Journal of the Warburg Institute, 1 (1937-8), 281-6 (esp. 281 for the quotation).

18 Die tafel van der voorsettincs des broots figuere van tsacrament des outaers.

19 See also François, 'Typology - Back with a Vengeance!', 122-4. See there for further references.

20 Edwards, Printing, Propaganda and Martin Luther, 123-7. Cf. Flood, 'Martin Luther's Bible Translation,' 54-9. One of the basic works remains Peter Martin, Martin Luther und die Bilder zur Apokalypse: Die Ikonographie der Illustrationen zur Offenbarung des Johannes in der Lutherbibel 1522 bis 1546 (Hamburg: Friedrich Wittig Verlag, 1983). Cf. Engammare, 'Les représentations de l'Écriture dans les Bibles illustrées du XVIe siècle,' 166-8.

21 Bart A. Rosier, The Bible in Print: Netherlandish Bible Illustration in the Sixteenth Century, trans. Chris F. Weterings, vol. 1 (Leiden: Foleor, 1997), 13-14, and esp. 51-8, 119-21. It is uncertain who used the woodblocks first, although Rosier seemed still convinced that it was Fuchs; Nelly de Hommel-Steenbakkers, 'Censorship or Self-Protection? Modifications in Apocalypse Illustrations in Sixteenth-Century Bibles Printed in the Low Countries,' in Infant Milk or Hardy Nourishment? The Bible for Lay People and Theologians in the Early Modern Period, eds Wim François and August den Hollander (Leuven: Peeters, 2009), 191-221, esp. 193-5.

22 Rosier, The Bible in Print, vol. 1, 54-5 and 21; De Hommel-Steenbakkers, 'Censorship or Self-Protection? Modifications in Apocalypse Illustrations,' 195-7.

23 See, for example, the horrified monk seeking protection at Babylon's burning (18th image to the Apocalypse) and the devil as a bearded monk in the Gospel story of the temptations in the desert (cf. Cebus Cornelis de Bruin, De Statenbijbel en zijn voorgangers: Nederlandse bijbelvertalingen vanaf de Reformatie tot 1637, rev. Frits G. M. Broeyer [Haarlem: Nederlands Bijbelgenootschap and Brussels: Belgisch Bijbelgenootschap, 1993], 168-9). 
24 See the discussion of 'Moses Explaining the Rights of Priests' and 'Josiah has the Book of Law Read' in Rosier, The Bible in Print, vol. 1, 118-19.

25 Rosier, The Bible in Print, vol. 1, 121. Cf. Engammare, 'Les représentations de l'Écriture dans les Bibles illustrées du XVIe siècle,' 184.

26 Cf. James Kearney, The Incarnate Text: Imagining the Book in Reformation England (Philadelphia, PA: University of Philadelphia Press, 2009), 22: 'Protestants would reject the written word as an image.' The Amsterdam scholar August den Hollander has, however, asked the question as to whether the dramatic diminution of images in Dutch Protestant Bibles should only be ascribed to the (alleged) Protestant hostility towards pictures and images, or whether this phenomenon has also to do with the move of the production to the North of the Low Countries, where the tradition of including images in books was less developed than in the South (Antwerp).

27 Cf. the tripartite division of manuscript marginalia, marks of active reading (such as underlinings), marks of ownership (for example signatures or shelf marks), and marks of recording (debts, marriages, births, accounts, and so on), in Brayman Hackel, Reading Material in Early Modern England, 138.

28 Cf. Sherman, Used Books, 76.

29 Cf. Sherman, Used Books, 79, also 83.

30 Inviolata, intacta et casta es Maria.

31 Brayman Hackel, Reading Material in Early Modern England, 100.

32 The text contained in the added manuscript pages is not taken from the Old Testament in the Dutch 'Louvain Bible' of 1548, but from its predecessor, the Vorsterman Bible. It looks as if the text of the complete Louvain Bible was not available when the manuscript pages were written. Indeed, a New Testament edition containing the text of the Louvain Bible had already been published a few weeks or even months before the complete edition was brought onto the market in September 1548. Obviously, the manuscript had been written immediately after the publication of the New Testament, in order to fill the lack in the liturgical lessons of the same, after which it was bound together with the printed work. On the book binding, see Luc Indestege, 'Das Bild Karls V. auf flämischen Einbänden des XVI. Jahrhunderts,' Gutenberg Jahrbuch [36] (1961), 309-18, esp. 311.

33 Dat geheel nieuwe Testament ..., trans. Nicholas van Winghe (Leuven: Bartholomeus van Grave, 1548) (signature Leuven, Maurits Sabbe Library, P 225.055.1 BIBL 1548).

34 See the description and commentary by Marcel Gielis on the following websites: http:// lyrawww.uvt.nl/ mgielis/geloof\%20in\%20beeld/Bloemaert\%20Intercessie.htm; https://adel bertdenaux.wordpress.com/2012/12/04/de-mariologie-van-adelbert-denaux-in-beeld/ (accessed 25 October 2015).

35 Brayman Hackel, Reading Material in Early Modern England, 196: 'Many early moderns read their books to pieces.'

36 In this regard ground-breaking research has been done by Mart van Duijn on the remaining copies of the 'Delft Bible,' the very first printed Bible in Dutch (1477): Mart van Duijn, 'Gods Woord gemeengoed: Een sociale geschiedenis van de Delftse Bijbel (1477-ca.1550)' (PhD dissertation, Rijksuniversiteit Groningen, 2014). 